Potravinarstvo Slovak Journal of Food Sciences

vol. 14, 2020, p. 1183-1190

https://doi.org/10.5219/1423

Received: 18 June 2020. Accepted: 16 December 2020.

Available online: 28 December 2020 at www.potravinarstvo.com

(C) 2020 Potravinarstvo Slovak Journal of Food Sciences, License: CC BY 3.0

ISSN 1337-0960 (online)

\title{
THE INFLUENCE OF CHOSEN ORGANIC FERTILIZERS ON QUALITATIVE PARAMETERS OF THREE DAUCUS CAROTA L. VARIETIES
}

\author{
Marcel Golian, Lucia Hlavačková, Adriána Mat’ová, Ivana Mezeyová, Miroslav Šlosár, \\ Alžbeta Hegedüsová, Samuel Adamec
}

\begin{abstract}
In rational nutrition, vegetables play an important role due to their high biological and low energy value. The most widespread vegetables in our country belong to root vegetables. They are grown mainly for bulbs, corms, rhizomes, fleshy roots, and hypocotyl tubers. Root vegetables can be eaten raw or cooked. Carrot (Daucus carota L.) is a basic representative of root vegetables. For the most valuable components counts beta-carotene - the major component of total carotenoids. This paper evaluates changes in total carotenoids, refractometric dry matter, and gravimetric dry matter in three varieties of carrot (Kamaran F1, Komarno F1, Romosa) grown in soil and climatic conditions ex-situ in Nitra. We have evaluated roots grown in non-fertilized soil, soil after application of manure, horticultural compost, and their combinations. The results show that the variants fertilized with compost and a mixture of compost and manure had the most considerable influence on the synthesis and content of total carotenoids as well as the content of dry matter and refractometric dry matter.
\end{abstract}

Keywords: total carotenoids; antioxidant; fertilizer; vegetable; quality

\section{INTRODUCTION}

Cultural plants are an essential part of civilization. Many of them had originally been harvested as wild plants, later on, cultivated and consciously bred. Vegetables generally represent the juicy parts of plants. They can be grown on arable land, but in the tropics and subtropics, some of the vegetables can be collected from the wild (eg. roots, leaves, etc.). In rational nutrition, vegetables play an important role because of their high biological and low energy value (Vargová, 2003). Vegetables are of great importance for health, especially in terms of the content of vitamins that affect normal metabolism. The beneficial effect of the contained minerals on the acid-base balance in the human body is also significant. Due to their low calorific value, vegetables can be extensively used in a weight-reduction diet. Vegetables, especially when fresh constitute a rich source of vitamins, primarily vitamins $\mathrm{A}$ and $\mathrm{C}$. Consumption of vegetables provide many health benefits, such as reducing the risk of heart disease, including heart attack, obesity, diabetes, and stroke. It protects against certain types of cancer and can also reduce the risk of developing kidney stones (Seljåsen et al., 2012). Carrots ranks among the 10 most important vegetable species in terms of cultivated areas' size and production volume indicated in tons (Simon and Goldman, 2007). Carrots produce strong roots with high nutritional value. It contains valuable components such as carotene, thiamine, and riboflavin. It is also a source of carbohydrates, proteins, fat, minerals, vitamin C, and calories (Yawalker, 1985). Ergun and Süslüoğlu (2018) state that carrots are primarily valued because of their high beta-carotene contents. In addition to that, the root contains various bioactive compounds including other forms of carotenoids, phenol compounds, and vitamins. Beta-carotene is known as provitamin $\mathrm{A}$ and it is known as a strong antioxidant. According to Oberbeil and Lentz (2003), carrots also have a high content of selenium, D, E, and $\mathrm{K}$ vitamins, essential oils, lecithin, potassium, calcium, magnesium, iron, copper, phosphorus, iodine, cobalt, and sugars. Among the sugars, the most commonly occurred are sucrose (about 50\%), glucose, and fructose (Šapiro and Raab, 1988). Terpenoids are responsible for astringency and bitterness (Kopec et al., 2010). The characteristic taste of carrots is given by their intense sweetness and minimal bitterness (Simon, 1982). Significant amounts of fiber are to be found in the roots. The acid content is low, with malic acid, citric acid, and oxalic acid being the most prominent of the variety of acids contained (Šapiro and Raab, 1988). At present, the total annual yield of carrots in Slovakia has a decreasing tendency compared to the past decade. In 2007 the total annual yield of carrots was $31,817 \mathrm{t}$ per 2,568 ha. Between 2007 and 2008, the yields lightly increased, reaching $37,155 \mathrm{t}$ per 2,562 ha. Afterward, between 2008 and 2010, the total annual yield of carrot mildly lessened up to $34,879 \mathrm{t}$ per 2,454 ha in 2010 . However, between 2010 and 2012 total annual crops decreased dramatically to as little as 6,685 t per 250 ha. 
Proceeding to $2012-2014$, the total annual crop of carrots was relatively stable, reaching 6,502 t per 232 ha in 2014 . Between 2014 to 2015 though, we were experiencing a slight increase in total annual yield which resulted in $10096 \mathrm{t}$ per 312 ha in 2015. Between 2015 and 2017, the total annual yield decreased again, in 2017 it decreased to 5, $730 \mathrm{t}$ per 185 ha. Average hectare yields in Slovakia in the last decade reached $16 \mathrm{t}$ (FAOSTAT, 2020).

\section{Scientific hypothesis}

The concentration of total carotenoids depends on the variety.

More intense usage of fertilizers can support the synthesis of carotenoids, refractometric dry matter, and total dry matter.

\section{MATERIAL AND METHODOLOGY}

\section{Characteristics of the research area}

The research was carried out in the form of a small-plot experiment under the conditions of the vegetable sampler of the Department of Vegetable Production in the area of Botanical Garden at the Slovak University of Agriculture in Nitra. We used four soil variants, the size of each was $6 \times 7 \mathrm{~m}\left(42 \mathrm{~m}^{2}\right)$. Monitored varieties are shown in Figure 1 and Figure 2.

\section{Variants}

1. variant with the application of livestock manure in the amount of 44 t.ha $^{-1}$ and compost applied in the amount of 44 t.ha' ${ }^{-1}$ (MH K).

2. variant with the application of livestock manure in the amount of 44 t.ha ${ }^{-1}(\mathrm{MH})$.

3. variant with the application of mature compost in the amount of 44 t.ha ${ }^{-1}(\mathrm{~K})$.

4. variant with non-fertilized soil (control variant) (KON).

By each variant, three experimental trials were carried out.

\section{Characteristics of monitored varieties Daucus carota 'Romosa' (Rom.)}

A profitable late Berlicum variety is characterized by exceptional external and internal root coloring. The roots are of high quality, cylindrical and $16-19 \mathrm{~cm}$ long. The flesh is juicy and delicious. This carrot variety reaches a vegetation period of 127 days from sowing to reaping. This variety is recommended for storage. It is suitable not only for storage but also for industrial processing. When densely sown, it is also suited for direct consumption (Bejo, 2016).

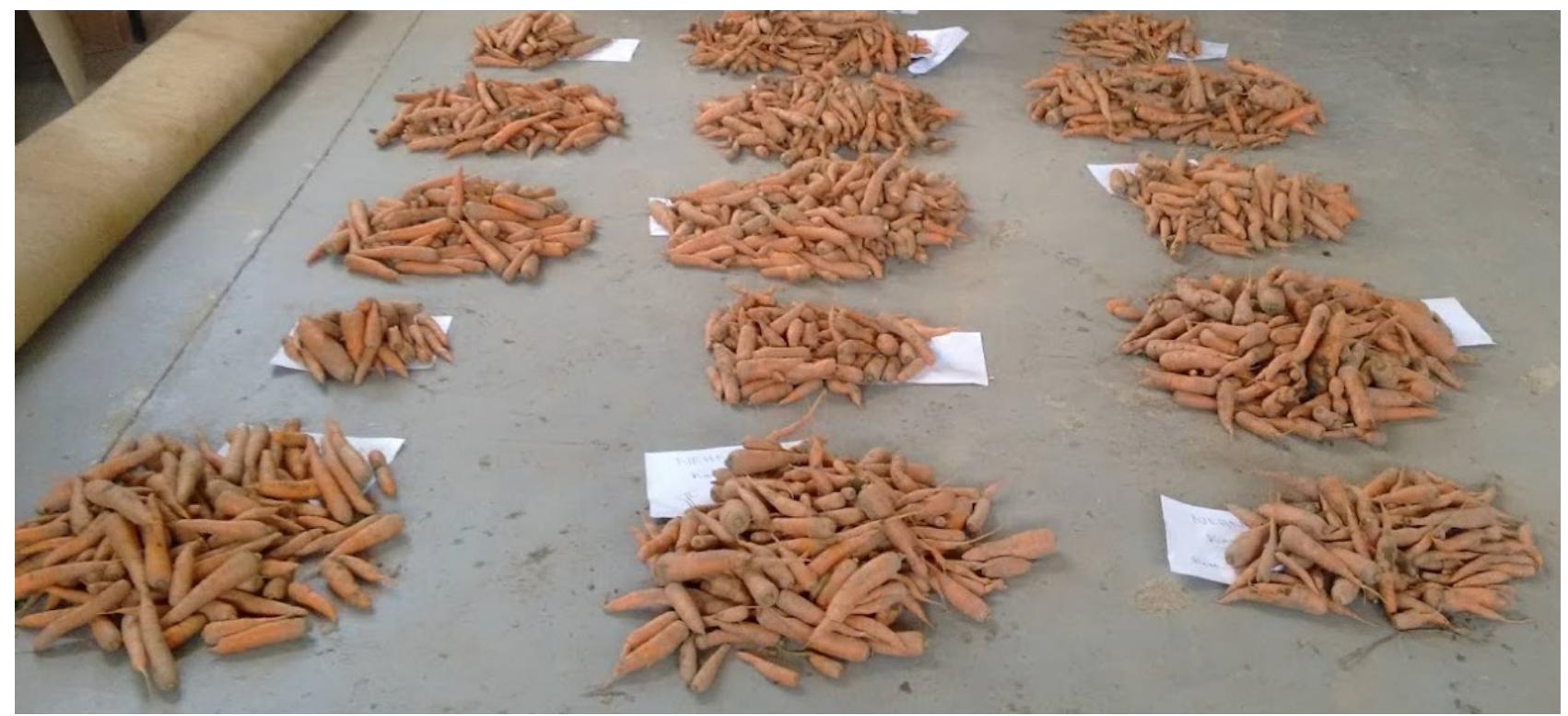

Figure 1 Examined carrot varieties, sorted by variety and variant.

Note: left: Kamaran F1, Komarno F1 and Romosa.

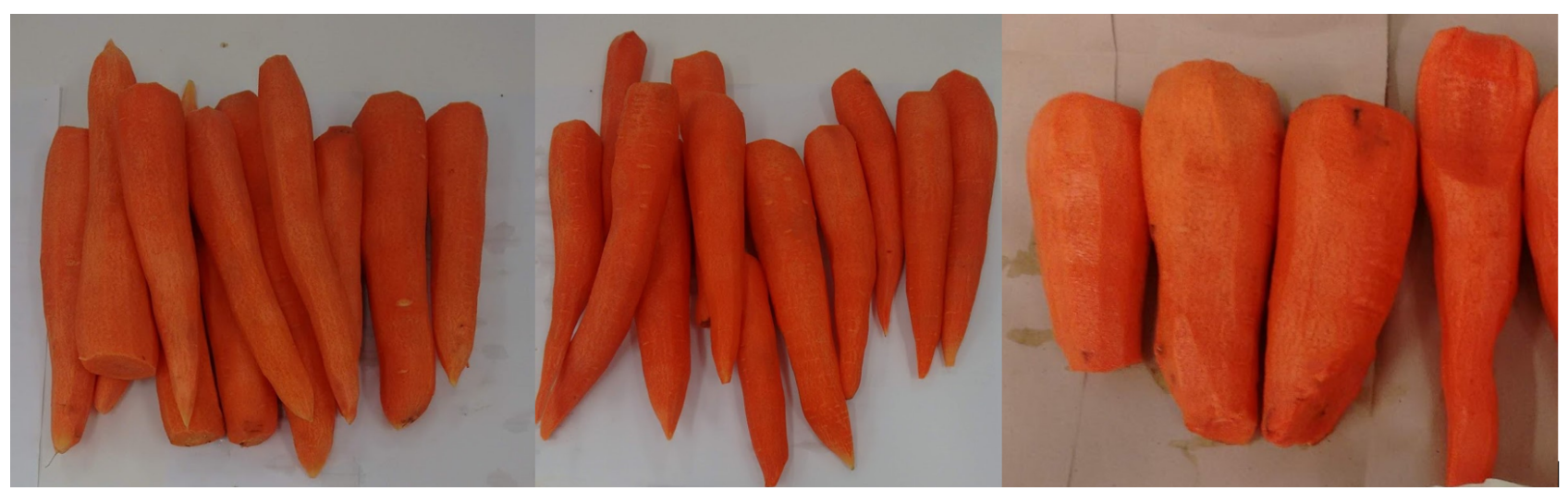

Figure 2 Examined carrot varieties.

Note: from the left - Kamaran F1, Romosa and Komarno F1. 


\section{Daucus carota 'Kamaran F1' (Cam.)}

This is a late and highly productive hybrid of the Berlicum and Flakkee variety. It forms dull-ended roots up to $26 \mathrm{~cm}$ long. It has excellent external and internal coloring. The roots weigh $300-500$ grams and have a diameter of $2.5-$ $4.5 \mathrm{~cm}$. Carrots of this variety are suitable for long-term storage. The vegetation period of Kamaran F1 variety in our climatic conditions reaches 135 days. It can accumulate less nitrate and is suitable for industrial processing and storage (Bejo, 2016).

\section{Daucus carota "Komarno F1" (Kom.)}

This variety of carrots is a late and very fruitful Flakkee type variety foremost suited for industrial processing. Komarno F1 variety is typical with high yields and high dry matter content. Its typical smooth conical roots with strong and healthy leaves of dark green color are very resistant to fungal and bacterial diseases. The roots have intense dark red coloring and weigh 200 to 500 grams. Vegetation time for this variety of carrots in our conditions is 161 days. This variety is excellent for freezing, production of carrot juice, and wherever an intense dark color of the final product is required. The variety is also suitable for storage (Bejo, 2016).

\section{Measurement methods of selected qualitative materials \\ Total carotenoid content}

The extraction of samples has been done at the Laboratory of Beverages, AgroBioTechResearch Center of SUA in Nitra. The measurement of total carotenoid content was realized in the laboratory of the Department of Vegetable Production of SUA (Slovak University of Agriculture) in Nitra. The content of total carotenoids was assessed by spectrophotometric measurement of substance absorbance in petroleum ether extract on Spectroquant $\AA$ Spectrophotometer Pharo 100 at $445 \mathrm{~nm}$ wavelengths (Hegedúsová et al., 2015). Calibration was not performed due to the calculation of the total carotenoid content, which was performed according to the average specific absorbance $\varepsilon$. The measurement was taken three times. Total carotenoid content was recalculated according to the relationship reported by Biehler et al. (2010).

\section{Determination of refractometric dry matter}

The refractometric dry matter was measured in triplicate by using a refractometer (type CRUESS DR201-95).

\section{Determination of dry matter}

The dry matter content was determined by using a gravimetric weighing method. The analyzed plant material was dried at $105^{\circ} \mathrm{C}$ up until the weight became stable.

\section{Statistical analysis}

Statistical analysis was performed by using Statgraphic Centurion XVII (StatPoint Inc. USA). The obtained results were evaluated by analysis of variance (ANOVA) and the average values were tested by LSD test at the significance level of $95 \%$.

\section{RESULTS AND DISCUSSION \\ Total carotenoid content}

Carotenoids are an important group of biologically active compounds attributed to a wide range of health benefits. These are natural pigments that occur mainly in vegetables but also in other natural resources such as fungi, algae, microorganisms, crustaceans, fish, birds but also mammals (Kulczyński a Gramza-Michałowska, 2019).

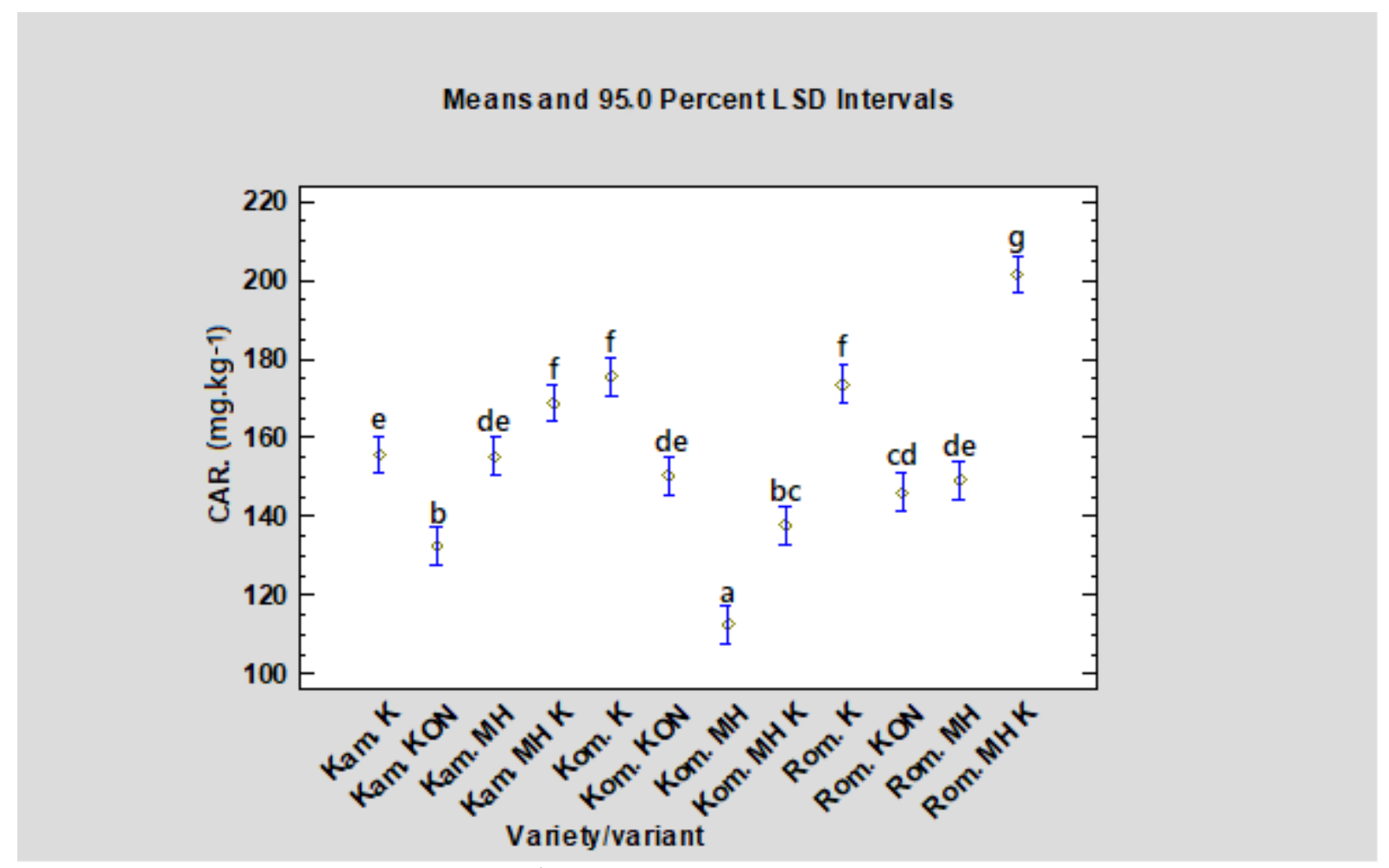

Figure 3 Total carotenoids content $\left(\mathrm{mg}_{\mathrm{kg}} \mathrm{kg}^{-1}\right)$ in varieties Kamaran F1, Komarno F1 and Romosa according to the variants. Note:The values in the columns with different letters are significantly different from each other. 
Based on our results (Figure 3), it is possible to find the highest content of carotenoids in the Romosa variety, namely in the Rom variant MH K (201.32 mg. $\left.\mathrm{kg}^{-1}\right)$. Subsequently, a decreasing trend was observed in the following order: Rom. K by 14\% (173.62 mg. $\mathrm{kg}^{-1}$ ), Rom. MH by $26 \%$ (148.96 mg. $\mathrm{kg}^{-1}$ ) and Rom. KON by $27 \%$ (146.03 mg. $\left.\mathrm{kg}^{-1}\right)$. The same findings concerning the variety's particularities were detected in the Kamaran F1 variety. The highest content of carotenoids was recorded in variant Kam. MH K (168.91 mg. $\left.\mathrm{kg}^{-1}\right)$. As for other variants from the Kamaran F1 variety, a decreasing trend can be observed in the following order: $\mathrm{K}$ by $7 \%\left(155.84 \mathrm{mg} . \mathrm{kg}^{-1}\right)$, Kam. MH by $8 \%$ (155.38 mg. $\mathrm{kg}^{-1}$ ) and Kam. KON by $21 \%$ (132.66 mg. $\left.\mathrm{kg}^{-1}\right)$ in terms of carotenoid content determination. Different findings were noted for the Komarno F1 variety. The highest content of total carotenoids in this variety was recorded in the variant Kom $\mathrm{K}\left(175.64 \mathrm{mg} \cdot \mathrm{kg}^{-1}\right)$. In other variations of Komarno F1 variety was detected a lower content of total carotenoids decreasing in the following order: Kom. KON by $14 \%$ (150.18 mg.kg ${ }^{-1}$ ), Kom. MH K by $22 \%$ (138.08 mg.kg $\left.{ }^{-1}\right)$ and Kom. MH 36\% (112.62 mg.kg-1 ${ }^{-1}$. Miękus et al. (2019) and Amorim-Carrilho et al. (2014) report that the total carotenoid content of carrots is generally $160-380 \mathrm{mg} \cdot \mathrm{kg}^{-1}$ of fresh matter. Fikselová et al. (2008) report that the carotenoid content of most varieties ranges from $60-$ $120 \mathrm{mg} \cdot \mathrm{kg}^{-1}$ of fresh matter, but some varieties have a carotenoid content of up to $300 \mathrm{mg} \cdot \mathrm{kg}^{-1}$ of fresh matter. The varieties examined in our study can certainly not be evaluated as highly above average regarding their content of carotenoids. Kaur and Sogi (2016) report a total carotenoid content of $324 \mathrm{mg} . \mathrm{kg}^{-1}$ while Saha et al. (2016) in their experiments set the highest content at $144 \mathrm{mg} . \mathrm{kg}^{-1}$. Kiraci and Padem (2016) observed purple varieties of carrots and found out that the content of beta-carotene (the main constituent of carotenoids in carrots) is 117 149 mg. $\mathrm{kg}^{-1}$. A study by Santos and Simon (2006) confirms that the content of carotenoids is genetically determined for individual varieties. Smoleń and Sady (2009) revealed no significant effect of $\mathrm{N}$-fertilization on carotenoid concentration in carrots. Our research has refuted this claim. However, obtained results confirm the findings of Evers (1989), who claims in his study that variants treated with $\mathrm{P}$ and $\mathrm{K}$ or NPK fertilizers were characterized by a higher carotene content in the roots.

Hochmuth, Brecht, and Bassett (1999) studied the total carrot root yield and the content of total carotenoids and sugars. They found the levels of $\mathrm{N}$ fertilization maximizing carrot root yield (in tonnes) also maximized carrot quality in terms of sugar and carotenoid levels. Kovács et al., (2012) verified the use of compost, mineral fertilization, and bacterial fertilization in carrot cultivation. The highest content of total carotenoids in the roots was detected in variants with compost. Recent studies have shown that the content of total carotenoids in carrot roots can change completely when the roots are exposed to light. Illuminated roots have chloroplasts with high lutein levels instead of beta-carotene-rich chromoplasts found in roots below the ground (Rodríguez-Concepción and Stange, 2013). From carrot production with an emphasis on the production of the high content of beta-carotene, it is important to choose the appropriate agrotechnical.

\section{Dry matter content}

The results (Figure 4) show that the highest dry matter content was determined in the Kamaran F1 variety, namely in the Kam. K (14.16\%) variant.

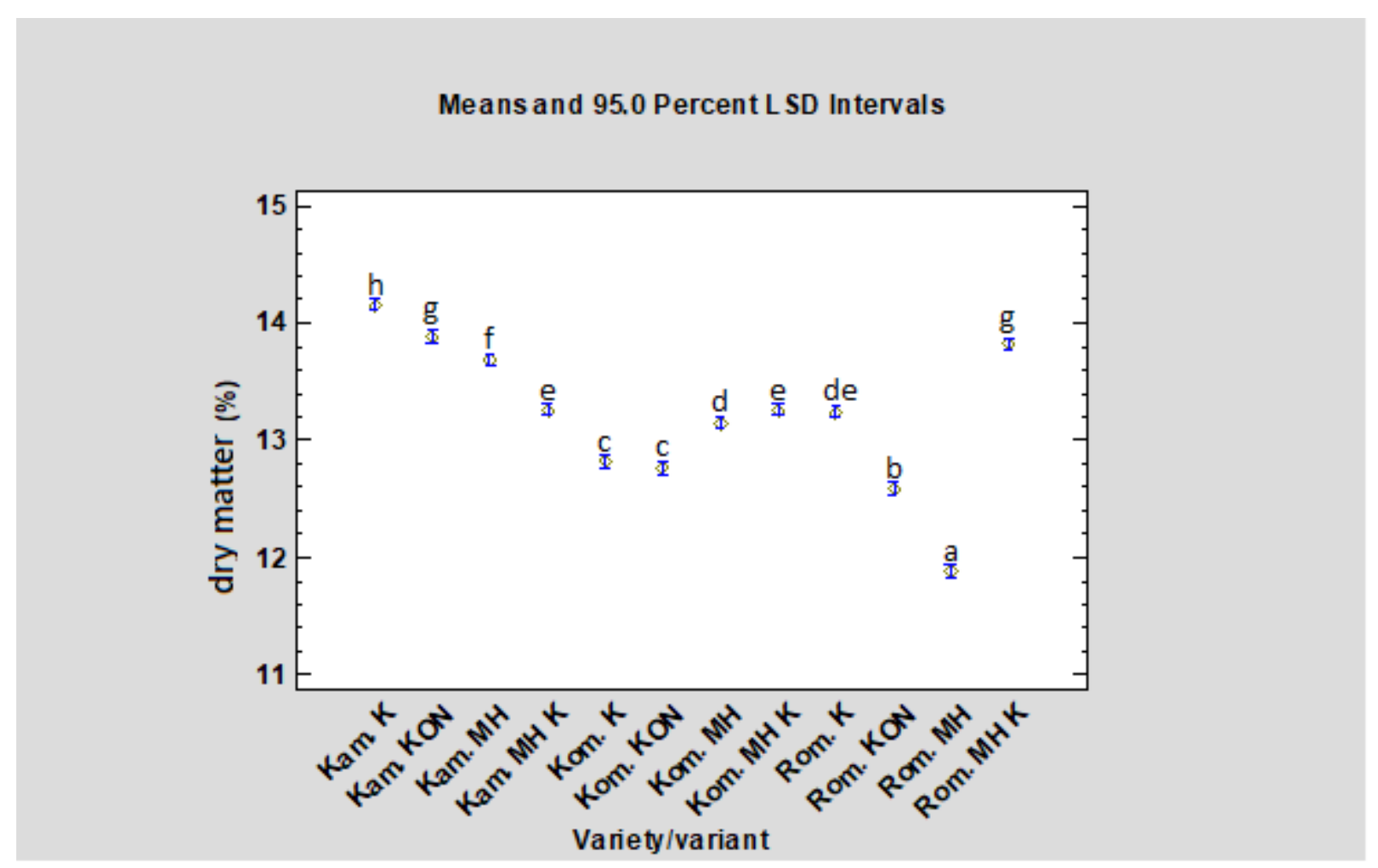

Figure 4 The dry matter content in (\%) in varieties Kamaran F1, Komarno F1 a Romos aaccording to the. Note: The values in the columns with different letters are significantly different from each other. 
In the case of the other variants (Kamaran F1 variety), the decreasing trend in the order of Kam. KON by $2 \%$ $(13.88 \%)$, Kam. MH by $3.3 \%$ (13.69\%) and Kam. MH K $6.4 \%(13.26 \%)$ can be noted in the dry matter contents. In the Romosa variety, other findings were detected in terms of variation effects. The highest dry matter content was determined in the Rom. MH K (13.82\%) variant. In the case of the other variants (Romosa variety), the decreasing trend in the order of Rom. K by $4.2 \%$ (13.24\%), Rom. KON by $8.9 \%(12.59 \%)$ and Rom. MH by $13.97 \%$ (11.89\%) can be observed in the dry matter contents. The highest dry matter content of Komarno F1 was determined in the variant Kom. MH K (13.26\%). In the case of other variants (Komarno F1 variety), the decreasing trend in the order of Kom. MH by $0.83 \%(13.15 \%)$, Kom. K by $3.3 \%(12.82 \%)$ and Kom. $\mathrm{KON}$ by $3,7 \%(12,77 \%)$ can be stated in the dry matter content. Variants fertilized with compost and a mixture of compost and livestock manure had the highest impact on the dry matter content. Bach et al. (2015) reported that the dry matter content of most varieties varied from 11.1 to 13.7 g. $100^{-1} \mathrm{~g}$ of fresh weight. However, the authors add that in 2009, the dry matter content was significantly higher $(p \leq 0.05)$ than in 2007 and 2008. In comparison with Bach, a relatively high average dry matter content was found in our study. Dhillon et al. (2016) reported that the dry matter content of the carrot varieties studied ranged from $6.68 \%$ to $8.70 \%$ (average $7.66 \%$ ). Compared to Dhillon, we again detected a significantly higher percentage of dry matter. However, the varieties examined by us cannot be assessed as highly above average concerning their dry matter content. Gopalan, Rama Sastry, and Balasubramanian (1991), Longvah et al. (2017), and Fanlégué et al. (2018) agree with us that the moisture content of carrots varies between 86 and 89\%. Kaur and Sogi (2016) determined a $10 \%$ dry matter.

\section{Refractometric dry matter}

The highest refractometric dry matter content was determined in the Kamaran F1 variety (Figure 5), namely in the Kam. variant $\mathrm{K}$ (11.98 ${ }^{\circ}$ Brix $)$. We observed a decreasing trend in the contents of the refractometric dry matter in other variants of Kamaran F1 variety with KON declining by $5.1 \%$ (11.37 ${ }^{\circ}$ Brix $)$, Kam. MH by $6.5 \%$ (11.2 ${ }^{\circ}$ Brix) and Kam. MH K by $10.02 \%$ (10.78 ${ }^{\circ}$ Brix). Different findings emerged from the measurements of the Romosa variety.

The highest refractometric dry matter content was determined in the Rom. variant MH K (11.22 ${ }^{\circ}$ Brix). Other variants of the Romosa variety showed a decreasing trend in the following order: $\mathrm{KON}$ by $3.48 \%$ ( $10.83^{\circ}$ Brix), Rom. $\mathrm{K}$ by $4.46 \%$ (10.72 ${ }^{\circ}$ Brix) and Rom. MH by $12.84 \%$ (9.78 ${ }^{\circ}$ Brix). Slightly different conclusions can be drawn from researching the Komarno F1 variety. The highest content of refractometric dry matter was determined in variant Kom. MH K (10.63 $\left.{ }^{\circ} \mathrm{Brix}\right)$. In the case of other variants (Komarno F1 variety) a similar decreasing trend was recorded in the refractometric dry matter content which declined in the following order: $\mathrm{MH}$ by $0.28 \%$ ( $\left.10.6^{\circ} \mathrm{Brix}\right)$, Kom. KON by $6.21 \%$ (9.97 ${ }^{\circ}$ Brix) and Kom. K by $7.06 \%$ $\left(9.88^{\circ}\right.$ Brix). Variants fertilized with compost and a mixture of compost and manure had the highest impact on the refractometric dry matter content. Valšíková et al. (2013) report that the average refractometric dry matter content of fresh carrot roots was $7.6^{\circ} \mathrm{Brix}$. Authors also recorded that after 14 days of package-free storage in a laboratory the refractometric dry mater values increased to $14.8^{\circ} \mathrm{Brix}$. In comparison with Valšíková, we detected higher average values of refractometric dry matter contents in our research. Seljåsen et al. (2013) state that the refractometric dry matter content values in carrots varied from $45-72 \mathrm{mg} . \mathrm{g}^{-1}$ of fresh matter $(60 \%)$ depending on the variety.

Means and 95.0 Percent L SD Intervals

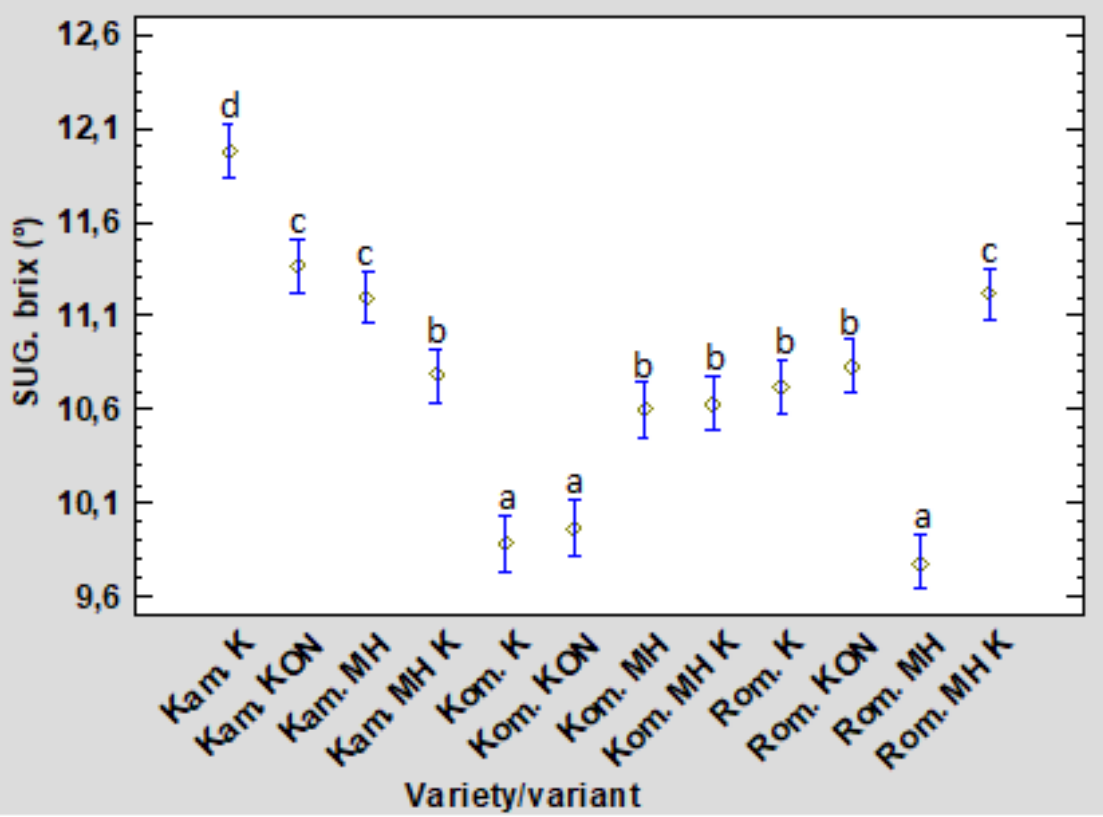

Figure 5 Refractometric dry matter content in Brix $\left(^{\circ}\right)$ in varieties Kamaran F1, Komarno F1 a Romosa according to the variants. Note: The values in the columns with different letters are significantly different from each other. 
Machewad et al. (2003) claim that carrot root is considered one of the tastiest and juiciest roots and the total soluble solids content mean value reaches approximately $12{ }^{\circ}$ Brix. Saha et al. (2016) detected results stretching from 6.7 to $10.48^{\circ}$ Brix. Similar findings $\left(6-8{ }^{\circ}\right.$ Brix $)$ were published by Jabbar et al. (2015); Gills et al. (1999) reported values ranging $8.6-10^{\circ} \mathrm{Brix}$; Holley et al. (2007) $7-10.5^{\circ} \mathrm{Brix}$; Nadulski et al. (2014) $8.2^{\circ} \mathrm{Brix}$; Evrendilek and Ozdemir (2019) reported values ranging from 7.2 to $9{ }^{\circ}$ Brix; and Santana-Gálvez et al. (2019) came with the resulting values of $8.1^{\circ}$ Brix. Comparing these to the results of our research, we detected lower values of carrots ${ }^{6}$ refractometric dry matter. Smoleń and Sady (2009) do not hold coincident opinions on the impact of fertilization (foliar) on refractometric dry matter content. In their experiments, the refractometric dry matter content increased in some cases, while decreased in others.

\section{CONCLUSION}

In four soil variants model varieties of carrots (Romosa, Kamaran F1, Komarno F1) were evaluated in terms of qualitative parameters (total carotenoids, dry matter, and refractometric dry matter). The study of total carotenoid content in carrot varieties shows that the most significant effect on the synthesis and carotenoid content was detected in the variants fertilized with compost and a mixture of compost and manure. Averaging the results from all four variants, the best source of carotenoids in terms of varieties was measured in the Romosa variety $\left(167.48 \mathrm{mg} \cdot \mathrm{kg}^{-1}\right)$. The lower content of total carotenoids was found in Kamaran F1 (153.19 mg. $\mathrm{kg}^{-1}, \quad 9 \%$ lower) and Komarno F1 (144.13 mg. $\mathrm{kg}^{-1}, 14 \%$ lower) varieties. The variants with compost and a mixture of compost and livestock manure had the highest influence on the content of dry matter. The Kamaran F1 variety was found to have the highest average dry matter content (13.75\%). Lower dry matter content was found in Romosa variety $(12.88 \%$, by $6.33 \%$ lower) and Komarno F1 variety (13\%, by $5.46 \%$ lower). What regards the refractometric dry matter, the highest effect on the varieties had variants fertilized with compost and a mixture of compost and livestock manure. Averaging the results of all the variants for the specific variety, the highest refractometric dry matter content was detected by the Kamaran F1 variety (11.33 ${ }^{\circ}$ Brix $)$. A lower dry matter content was found in the Romosa variety (10.64 ${ }^{\circ}$ Brix, lower by $6.09 \%)$ and Komarno F1 (10.27 ${ }^{\circ}$ Brix, lower by $9.36 \%$ )

\section{REFERENCES}

Amorim-Carrilho, K. T., Cepeda, A., Fente, C., Regal, P. 2014. Review of methods for analysis of carotenoids. TrACTrends Anal. Chem, vol. 56, no. 2014, p. 49-73. https://doi.org/10.1016/j.trac.2013.12.011

Bach, V., Kidmose, U., Kristensen, H. L., Edelenbos, M. 2015. Eating Quality of Carrots (Daucus carota L.) Grown in One Conventional and Three Organic Cropping Systems over Three Years. Journal of Agricultural and Food Chemistry, vol. 63, p. 9803-9811. https://doi.org/10.1021/acs.jafc.5b03161

Bejo, Z. 2016. Catalogue of vegetableseeds. Bejo Bohemia, p. 75 .

Biehler, E., Mayer, F., Hoffmann, L., Krause, E., Bohn, T. 2010. Comparison of 3 Spectrophotometric Methods for Carotenoid Determination in FrequentlyConsumedFruits and
Vegetables. Journal of Food Science, vol. 75, no. 1, p. 55-61. https://doi.org/10.1111/j.1750-3841.2009.01417.x

Dhillon, H., Dhillon, T., Devi, R. 2016. Quality Characterization in Carrot (Daucuscarota L.) Germplasm. Indian Journal of Ecology, vol. 43, no. 1, p. 000-000.

Ergun, M., Süslüoğlu, Z. 2018. Evaluating carrot as a functional food. Middle East Journal of Science, vol. 4, no. 2, p. 113-119. https://doi.org/10.23884/mejs.2018.4.2.07

Evers, A. M. 1989. Effects of different fertilization practices on the carotene content of carrot. Agricultural and Food Science, vol. 61, no. 1, p. 7-14. https://doi.org/10.23986/afsci.72347

Evrendilek, G., Ozdemir, P. 2019. Effect of various forms of non-thermal treatment of thequality and safety in carrots. $L W T$, vol. 105, no. 2019, p. 344-354. https://doi.org/10.1016/j.lwt.2019.02.031

Fanlégué, C., Touré, A., Casimir, S., Adama, C., Réné, S. 2018. Physicochemical and Nutritional Properties of Varieties of Carrot (Daucus carota) grown in Region of Korhogo, North of Côted'Ivoire. International Journal of Environment, Agriculture and Biotechnology, vol. 3, no. 3, p. 792-798. https://doi.org/10.22161/ijeab/3.3.11

FAOSTAT. 2020 .

Fikselová, M., Šilhár, S., Mareček, J., Frančáková, H. 2008. Extraction of carrot (Daucus carota L.) Carotenes under different conditions. Czech J. Food Sci., vol. 26, no. 4, p. 268274. https://doi.org/10.17221/9/2008-CJFS

Gills, L. A., Resurreccion, A. V. A., Hurst, W. C., Reynolds, A. E., Phatak, S. C. 1999. Sensory profiles of carrot (Daucus carota L.) cultivars grown in Georgia. Hort. Science, vol. 34, no. 4, p. 625-628. https://doi.org/10.21273/hortsci.34.4.625

Gopalan, C., Rama Sastry, B. V., Balasubramanian, S. C. 1991. Nutritivevalue of Indianfoods. Hyderabad : National Institute of Nutrition, p. 47.

Hegedüsová, A., Mezeyová, I., Andrejiová, A. 2015. Metódy stanovenia vybraných biologicky aktivnych látok (Determination methods of selected biologically active substances). Nitra, Slovak Republic : SUA, p. 72. ISBN 97880-552-1420-7. (in Slovak)

Hochmuth, G., Brecht, J., Bassett, M. 1999. Nitrogen Fertilization to Maximize Carrot Yield and Quality on a SandySoil. Hort. Science: a publication of the American Society for Horticultural Science, vol. 34, no. 4, p. 641-645. https://doi.org/10.21273/HORTSCI.34.4.641

Holley, S. L., Edwards, C., Thorngate, J., Fellman, J., Matiinson, D. S., Sorensen, E. J., Dougherty, R. H. 2007. Chemical Characterization of differentlines of Daucus Carota L. Roots. Journal of Food Quality, vol. 23, no. 2000, p. 487502. https://doi.org/10.1111/j.1745-4557.2000.tb00574.x

Jabbar, S., Abid, M., Hu, B., Hashim, M., Lei, S., Wu, T., Zeng, X. 2015. Exploring the potential of thermosonication in carrot juice processing. Journal of Food Science and Technology, vol. 52, no. 11, p. 7002-7013. https://doi.org/10.1007/s13197-015-1847-7

Kaur, A., Sogi, D. S. 2016. Effect of osmotic dehydration on physico-chemical properties and pigment content of carrot (Daucus carota L) during preserve manufacture. J. Food Proces. Preserv., vol. 41, p. 1-6. https://doi.org/10.1111/jfpp.13153

Kiraci, S., Padem, H. 2016. The Selection of Purple Carrot Lines Has Superior Technological Characteristics in Turkey. Acta Scientiarum Polonorum. Hortorumcultus $=$ Ogrodnictwo , vol. 15 , no. 1, p. 89-99.

Kopec, R. E., Riedl, K. M., Harisson, E. H., Curley, R. W., Hruszkewycz, D. P., Clinton, S. K., Schwartz, S. J. 2010. 
Identification and Quantification of Apo-lycopenals in Fruits, Vegetables, and Human Plasma. Journal of Agricultural and Food Chemistry, vol. 58, no. 6, p. 3290-3296. https://doi.org/10.1021/jf100415z

Kovács, A., Krempet, R., Jakab, A., Szabó, A. 2012. Organic and mineral fertilizer effects on theyield and mineralcontents of carrot (Daucus carota). International Journal of Horticultural Science, vol. 18, no. 1, p. 69-74. https://doi.org/10.31421/IJHS/18/1/996

Kulczyński, B., Gramza-Michałowska, A. 2019. The Profile of Carotenoids and Other Bioactive Molecules in Various Pumpkin Fruits (Cucurbita maxima Duchesne) Cultivars. Molecules, vol. 24, no. 18, p. 3212. https://doi.org/10.3390/molecules24183212

Longvah, C., Ananthan, R., Bhaskarachary, K.,Venkaiah, K. 2017. Indian Food Composition Tables. Hyderabad: National Institute of Nutrition, p. 52.

Machewad, G. M., Kulkarni, D. N., Pawar, V. D., Surve, V. D. 2003. Studies on dehydration of carrot (Daucus carota L.). Journal of Food Science and Technology, vol. 40, no. 4, p. 406408.

Miękus, N., Iqbal, A., Marszałek, K., Puchalski, C., Świergiel, A. 2019. Green Chemistry Extractions of Carotenoids from Daucus carota L. - Super critical Carbon Dioxide and Enzyme - Assisted Methods. Molecules, vol. 24, no. 23, p. 4339. https://doi.org/10.3390/molecules24234339

Nadulski, R., Grochowicz, J., Sobczak, P., Kobus, Z., Panasiewicz, M., Zawiślak, K., Mazur, J., Starek, A., Żukiewicz-Sobczak, W. 2014. Application of Freezing and Thawing to Carrot (Daucus carota L.) Juice Extraction. Food and Bioprocess Technology, vol. 8, no. 1, p. 218-227. https://doi.org/10.1007/s11947-014-1395-6

Oberbeil, K., Lentzová, C. 2003. Ovoce a zelenina jako lék (Fruits and Vegetablesas a Medicine: The Dietthatheals). Prague, Czech Republic : Fortuna Print, vol. 2, p. 294. ISBN: 80-7321-067-3. (in Czech)

Rodríguez-Concepción, M., Stange, C. 2013. Biosynthesis of carotenoids in carrot: An underground story comes to light. Archives of biochemistry and biophysics, vol. 539, no. 2, p. 110-116. https://doi.org/10.1016/j.abb.2013.07.009

Saha, S., Kalia, P., Sureja, A., Sarkar, S. 2016. Breeding tropical carrots (Daucus carota) for enhanced nutrition and high temperature stress. Indian Journal of Agricultural Sciences, vol. 86, no. 7, p. 940-945.

Santana-Gálvez, J., Santacruz, A., Cisneros-Zevallos, L., Jacobo-Velázquez, D. A. 2019. Postharvest Wounding Stress in Horticultural Crops as a Tool for Designing Novel Functional Foods and Beverages with Enhanced Nutraceutical Content: Carrot Juice as a Case Study. Journal of Food Science, vol. 84, no. 5, p. 1151-1161. https://doi.org/10.1111/1750-3841.14588

Santos, C. A., Simon, P. W. 2006. Heritabilities and Minimum Gene Number Estimates of Carrot Carotenoids. Euphytica, vol. 151, no. 1, p. 79-86. https://doi.org/10.1007/s10681-006-9130-7

Seljåsen, R., Kristensen, H. L., Lauridsen, C., Wyss, G. S., Kretzschmar, U., Birlouez-Aragone, I., Kahl, J. 2013. Quality of carrots as affected by pre - and postharvest factors and processing. J. Sci. Food Agric., vol. 93, no. 11, p. 2611-2626. https://doi.org/10.1002/jsfa.6189

Seljåsen, R., Lea, P., Torp, T., Riley, H., Berentsen, E., Thomsen, M., Bengtsson, G. B. 2012. Effects of genotype, soil type, year and fertilisation on sensory and morphological attributes of carrots (Daucus carota L.). Journal Sci. Food Agric., vol. 92, no. 8, p. 1786-1799. https://doi.org/10.1002/jsfa.6189
Simon, P. W. 1982. Genetic variation for volatile terpenoids in roots of carrot, Daucus carota, backcrosses and F2 generations. Phytochemistry, vol. 21, p. 875-879.

Simon, P. W., Goldman, I. L. 2007. Carrot. In Singh, R. J. Genetic Resources, Chromozome Engineering a Crop Improvement Series, vol. 3. p. 497-517. ISBN 9780367389956. https://doi.org/10.1002/jsfa.5548

Smoleń, S., Sady, W. 2009. The effect of various nitrogen fertilization and foliar nutrition regimes on the concentrations of sugars, carotenoids and phenolic compounds in carrot (Daucus carota L.). Scientia Horticulturae, vol. 120, no. 3, p 315-324. https://doi.org/10.1016/j.scienta.2008.11.029

Šapiro, D. K., Raab, Č. 1988. Ovoce a zelenina ve výživě člověka (Fruits and Vegetables in human Nutrition). Praque, Czech Republic : Státní zemědělské nakladatelství, p. 226227. ISBN: 5-7860-0431-7. (in Czech)

Valšíková, M., Šlosár, M., Ryban, R., Shehata, S., Hegedüsová, A. 2013. Changes in Vitamin C Content and SolubleSolids of Carrot Content (Daucus carota L.) During Storage. Acta Horticulturae et Regiotecturae, vol. 16, no. 1, p. 1-3. https://doi.org/10.2478/ahr-2013-0001

Vargová, E. 2003. Zeleninárstvo (Vegetable production). Nitra: SPU, vol. 1, p. 129, ISBN: 80-8069-218-1. (in Slovak)

Yawalker, K. S. 1985. Vegetable Crops in India. $3^{\text {rd }}$ ed. Nagpur India : Agricultural Horticultural Publishing House, p. 166-170.

\section{Acknowledgment:}

This publication was supported by the Operational program Integrated Infrastructure within the project: Demand-driven research for the sustainable and inovative food, Drive4SIFood 313011V336, cofinanced by the Euruopean Regional Development Fund, KEGA 018SPU-4/2020 and by AgroBioTech Research Centre built in accordance with the project Building „AgroBioTech" Research Centre ITMS 26220220180 .

\section{Contact address:}

* Marcel Golian, Slovak University of Agriculture in Nitra, Horticulture and Landscape Engineering Faculty, Department of Vegetable Production, Tr. A. Hlinku 2, 949 76 Nitra, Slovakia, Tel.: +421376414322,

E-mail: xgolian@uniag.sk

ORCID: https://orcid.org/0000-0001-7266-7099

Lucia Hlavačková*, NOVOFRUCT SK, s.r.o., Komárňanskácesta 13, 94043 NovéZámky, Slovakia, Tel:+421918756972,

E-mail: hlavackova@,novofruct.sk

ORCID: https://orcid.org/0000-0002-7689-1079

Adriána Mat'ová, Slovak University of Agriculture in Nitra, Horticulture and Landscape Engineering Faculty, Department of Vegetable Production, Tr. A. Hlinku 2, 949 76 Nitra, Slovakia, Tel.: +421376414239,

E-mail: a.lidikova@gmail.com

ORCID: https://orcid.org/0000-0003-3325-0834

Ivana Mezeyová, Slovak University of Agriculture in Nitra, Horticulture and Landscape Engineering Faculty, Department of Vegetable Production, Tr. A. Hlinku 2, 949 76 Nitra, Slovakia, Tel.: +421376414243,

E-mail: ivana.mezeyova@uniag.sk

ORCID: https://orcid.org/0000-0001-5405-5611

Miroslav Šlosár, Slovak University of Agriculture in Nitra, Horticulture and Landscape Engineering Faculty, Department of Vegetable Production, Tr. A. Hlinku 2, 949 76 Nitra, Slovakia, Tel.: +421376414261, 
E-mail: miroslav.slosar@,uniag.sk

ORCID: https://orcid.org/0000-0001-8692-405X

Alžbeta Hegedűsová, Slovak University of Agriculture in Nitra, Horticulture and Landscape Engineering Faculty, Department of Vegetable Production, Tr. A. Hlinku 2, 949 76 Nitra, Slovakia, Tel.: +421376414712,

E-mail: alzbeta.hegedusova@uniag.sk

ORCID: https://orcid.org/0000-0001-6994-1077
Samuel Adamec, Slovak University of Agriculture in Nitra, Horticulture and Landscape Engineering Faculty, Department of Vegetable Production, Tr. A. Hlinku 2, 949 76 Nitra, Slovakia, Tel.: +421376414239, E-mail: samo.joker@gmail.com ORCID: https://orcid.org/0000-0001-6423-7005

Corresponding author: * 